\title{
Recent Updates in Cancer Immunotherapy
}

\author{
Man Ki Chung and Bo Young Kim \\ Department of Otorhinolaryngology-Head and Neck Surgery, Samsung Medical Center, Sungkyunkwan University School of Medicine, \\ Seoul, Korea
}

\section{암 면역 치료의 최신 지견}

정 만 기·김 보 영

성균관대학교 의과대학 삼성서울병원 이비인후과학교실

\author{
Received February 23, 2015 \\ Accepted March 20, 2015 \\ Address for correspondence \\ Man Ki Chung, MD, PhD \\ Department of Otorhinolaryngology- \\ Head and Neck Surgery, Samsung \\ Medical Center, Sungkyunkwan \\ University School of Medicine, \\ 81 Irwon-ro, Gangnam-gu, \\ Seoul 135-710, Korea \\ Tel +82-2-3410-3579 \\ Fax +82-2-3410-3879 \\ E-mail manki.chung@gmail.com
}

Immune system is believed to play an important role in cancer initiation as well as its progression, as evidenced by many studies revealing suppressed, defective anti-tumor immunity in cancer patients. Modulating various components in immune surveillance, such as cytokine, antigenpresenting cells, or B/T lymphocytes, to control and eradicate cancer has been an attractive theme, however, preclinical/clinical trials have not been successful enough to introduce immunotherapy into practice. Recently, enthusiasm on cancer immunotherapy has been revived mostly due to 1) growing body of data on the mechanism of immune checkpoint in cancer, and 2) promising studies performed in advanced, solid cancer patients treated with blocking antibodies targeting cytotoxic T lymphocyte-associated antigen- 4 or programmed cell death protein-1 pathways. The immune checkpoints blockade is likely to be a novel armament in cancer management as the outcomes of ongoing clinical trials are released in future.

Korean J Otorhinolaryngol-Head Neck Surg 2015;58(7):449-55

Key Words Cancer - Cytotoxic T lymphocyte-associated antigen · Head and neck · Immune $\cdot$ Programmed cell death protein.

\section{서 론}

면역 체계(immune system)는 면역 반응의 활성(activation) 과 억제(inhibition)의 적절한 균형을 통해 외부로부터 유입 되는 항원(antigen) 및 자가 항원(self-antigen)에 대한 방어 작용을 유지하게 되는데, 이 과정에서 항원에 의해 활성화된 $\mathrm{T}$ 림프구 및 면역 체계 내의 다양한 세포들 간의 수용체-리 간드(receptor-ligand) 결합이 핵심을 이루며, 이러한 면역 반 응은 암의 발생(carcinogenesis) 뿐만 아니라 치료 과정(antitumor immunity)에 중요한 역할을 한다고 알려져 있다.1)

최근 많은 연구결과를 통해, 두경부암을 포함한 많은 암에 서 정상적인 면역 및 효과적인 항암 면역 기전의 저하가 밝혀 졌는데, 특히 두경부암 환자에서 정상 대조군에 비해 절대 림 프구수 감소, ${ }^{2)}$ 면역 억제성 조절 $\mathrm{T}$ 림프구(regulatory $\mathrm{T}$ lymphocyte, Treg) 증가, ${ }^{3,4)}$ 암 연관 대식세포(tumor-associated macrophage)의 증가, ${ }^{5)}$ 암 연관 림프구의 항원 표현기능 저하 (down-regulation of antigen expression), ${ }^{6}$ 세포독성 $\mathrm{T}$ 림프 구(cytotoxic T lymphocyte)의 자발적 세포자살(apoptosis) $)^{7)}$ 등의 특성을 보이고 있다. 이외에도, 암에서 분비되는 혈관내 피세포증식인자(vascular endothelial growth factor), ${ }^{8)}$ 프로 스타글란딘 E2, ${ }^{9,10)}$ 형질전환성장인자(transforming growth factor- $\beta),{ }^{11)}$ interleukin-10 등에 의해 면역 기전의 직접적인 억제가 발생하여 항암 면역의 기능이 더욱 저하되게 된다. 두경부암 뿐만 아니라 다른 여러 종양에서 암세포 억제 효 과(anti-cancer effect)와 세포 독성 $\mathrm{CD}^{+} \mathrm{T}$ 림프구의 분화 를 유도할 수 있는 보조 $\mathrm{T}$ 세포-1(T helper-1 cell)이 감소해 있는 반면, 길항적으로 작용하는 보조 $\mathrm{T}$ 세포-2(T helper-2 cell)가 증가해 있는 것을 통해 종양의 발생에 면역 반응이 관 여함을 간접적으로 알 수 있다. ${ }^{12)}$

흥미로운 점은 암의 진행뿐 아니라, 암에 대한 직접적인 
치료인 항암화학치료(chemotherapy)와 방사선 치료(radiation therapy)에서도 치료 과정에 암세포에 대한 면역 체계의 조 절이 관여한다는 직, 간접적인 연구 결과들이 보고되어 있는 데, 악성 흑색종, 림프종, 신장암 등에서 외부 방사선 조사치 료 시, 치료영역 밖의 암도 호전을 보이는 현상과, 그 근거로 인체에 대한 외부 방사선 조사 시, 암 특이 항체와 $\mathrm{T}$ 림프구 의 활성화 영향으로 인한 암 치료효과를 보일 수 있다는 연 구 $^{13,14)}$ 등이 있다. 또한, 항암화학요법 시, 고용량의 항암화학 제에서는 면역 반응이 억제되지만, 저용량의 항암화학제의 경 우 오히려 항암 면역 반응이 자극, 유도된다는 보고도 있다.

암 면역 치료(cancer immunotherapy)는 암과 면역 체계의 밀접한 연관성에 대한 자료를 근거로 암 주변 미세환경이나 숙주의 면역 체계를 조절함으로써, 기존의 세포 독성 항암화 학치료 및 방사선 치료의 효과를 극대화하려는 연구 분야이 다. 암 면역 치료에 대한 시도는 1990년부터 다양하게 시도되 어, 면역 자극 싸이토카인(cytokine)을 이용한 면역 치료, 암 백 신요법, 양자 $\mathrm{T}$ 림프구 요법(adoptive $\mathrm{T}$ lymphocyte therapy) 등을 중심으로 전임상 및 초기 임상연구가 시행되었으나, 약 물의 국소 전달기전이나 전신 독성문제, 주목할 만한 치료 성적 부족 등으로 인해 실질적인 임상적용으로 이어지지 못 했다. 하지만, 최근 면역 치료에 대한 관심이 다시 증폭된 계 기가 있는데, 표적치료제의 일종인 cetuximab의 치료 작용 중 면역기전이 관여한다는 점, 암의 면역회피기전에 대한 연 구성과, 그리고 면역 관문(immune checkpoint) 차단을 위 해 단클론 항체를 사용한 초기 임상연구에서 악성 흑색종뿐 아니라, 두경부암과 같이 비면역성 고형암인 비소세포성 폐 암 등에서도 만족할 만한 임상 성적을 보인 점 등이다. ${ }^{15)}$

본 리뷰에서는 기존의 여러 가지 면역 치료법과 함께 최근 주요 면역 관문 차단(immune checkpoint blockage)에 작용 하는 항체 치료법으로 새롭게 주목 받고 있는 1) 세포 독성 $\mathrm{T}$ 림프구 연관 항원-4(cytotoxic $\mathrm{T}$ lymphocyte-associated antigen-4, CTLA-4)와, 2) 계획된 세포소멸 단백질-1(programmed cell death protein 1, PD-1/PD-L1 pathway)을 중 심으로 주요 기전, 전임상/임상 적용 성적, 향후 적용 가능성 에 대해 알아보고자 한다.

\section{본 론}

\section{싸이토카인 요법(Cytokine therapy)}

싸이토카인에 기반한 면역치료는 두경부암에서 국소주입 또는 전신주입법을 통해 다양하게 시도되었는데, 임상에 적 용될 만큼 좋은 성적을 보이지는 못하였다. 그 중 가장 많이 연구된 염증 유발성 interleukin-2(IL-2)는 T 림프구의 항원
특이성 증가, 비특이적인 자연살해세포(natural killer cell) 및 림포카인 활성 살생세포(lymphokine-activated killer cell) 의 활성화에 기여한다고 알려져 있다. 두경부암 환자에서 암 주변에 주입한 IL-2에 의해 $\mathrm{T}$ 림프구의 세포독성이 증가하 고, 말초혈액 내 자연살해세포가 증가한다는 보고가 있는 데, ${ }^{16)}$ 이를 근거로 한 임상연구는 상반된 결과를 보이고 있 다. 구강과 구인두암 환자를 대상으로 수술 및 방사선 치료 후, 종양주변 IL-2 주입을 시도하여 5년 생존율의 향상을 보 인 임상 3 상 연구 ${ }^{17}$ 가 있는 반면, 치료 불응성 비인두암에서 전신적으로 $\mathrm{IL}-2$ 를 주입한 임상 2 상 연구 ${ }^{18)}$ 는 치료 이득이 없 는 것으로 보고된 바 있다. 따라서, IL-2의 주입은 확립된 두 경부암 치료의 임상 적용에는 무리가 있다고 할 수 있다. 단 독으로 IL-2를 투여하는 대신, 세포에서 유도된 IL-1, IL-2, IL-6, IL-8, 종양괴사인자(tumor necrosis factor- $\alpha$ ), interferon- $\gamma(\mathrm{IFN}-\gamma)$, granulocyte-colony stimulating factor, granulocyte-macrophage colony stimulating factor 등의 혼합물을 사용하는 iroquois homeobox protein 2(IRX-2) 제제 주입 방법은 2 4 병기 두경부 암 환자를 대상으로 한 임 상 2상 연구에서 수술 전에 cyclophosphamide, indomethacin 등과 함께 투여하였을 때 $74 \%$ 환자에서 치료 전 암이 줄거나 크기가 유지되었고, 수술 후 검체에서 대조군에 비해 원발암과 림프절 내에 림프구의 침윤이 유의하게 증가하면 서 생존율 향상과 연관성을 보이는 것으로 나타났다..$^{19-21)}$ 현 재 IRX-2를 이용한 대규모, 다기간, 임상 3 상이 진행 중이어 서 두경부암에서 적용할 만한 치료 성적 및 허용 가능한 정 도의 독성을 보일지 지켜봐야 하겠다.

\section{암 백신(Cancer vaccine)}

암 백신은 암 연관 또는 암 특이적 항원을 주요조직적합복 합체(major histocompatibility complex) 형식으로 $\mathrm{T}$ 림프 구에 제시하거나 암 세포의 표면에 발현시켜서 B 림프구의 항원 인식을 유도하는 전략을 사용한다. 이때, 암 항원에 의 한 면역 반응성을 증가시키기 위해 다양한 항원 전달 수단을 이용하는데, 재조합(recombinant) 바이러스나 박테리아, 또 는 전체 암세포를 같이 사용하거나 활성화된 수지상 세포 등 을 같이 이용하는 방법이 있다. 특히, 수지상 세포 백신은 강 력한 수지상 세포의 항원 제시능력을 이용하는데, 진행된 두 경부암 환자를 대상으로 한 임상 1 상 연구에서, 야생형(wild type) p53 펩타이드로 자극시킨 수지상 세포를 세 차례 주입 하여, 2년 무병생존율 $88 \%$ 의 성적을 보고한 바 있으며, 같은 연구에서 백신을 투여 받은 환자군에서 면역 억제성 Treg가 감소하면서, $\mathrm{p} 53$ 특이적 $\mathrm{T}$ 림프구가 증가한 점을 수지상 세 포 백신에 의한 효과로 제시하고 있다. ${ }^{22)}$ 하지만 아직까지 두 
경부암 및 타 암종의 임상 치료에 적용할 만큼 충분한 전향 적 임상연구 결과가 없다는 점이 문제이다.

\section{면역 관문 차단(Immune checkpoint blockade)}

면역 반응은 자극(activation)과 억제(inhibition) 사이의 균 형 유지가 중요한데, 면역 자극이 약해질 경우 무감작 현상 (anergy)과 암 진행이 나타날 수 있고, 면역 억제가 부족할 경 우 자가면역반응 또는 조절되지 않는 면역반응이 나타날 수 있다. 면역 조절/관문(immune checkpoints)은 면역 반응의 상호 억제 신호(co-inhibitory stimulus)를 유발하는 면역 체 계 내의 세포 표면 분자들(surface molecules)을 일컬으며, ${ }^{1)}$ 면역 관문치료는 이러한 면역 관문을 표적으로 하는 항체를 통해 면역 반응을 조절함으로써 암을 조절 및 제거하려는 새 로운 연구분야이다. ${ }^{23)}$ 최근, 전반적으로 면역 억제력이 높아 져 있는 암에서 효과적인 면역반응의 진행을 막는 관문에 대 한 많은 연구가 이루어지면서, 대표적으로 주목 받고 있는 기 전으로 1) CTLA-4에 의한 T 림프구 억제기전과, 2) 기 활성 화된 T 림프구를 억제하는 PD-1/PD-L1 기전이 있다. 이를 통 해, 암 세포는 적응면역반응(adaptive immune system)의 인 지를 피하거나 교란하면서 효율적인 면역 회피를 유지하게 된다. 면역 관문억제를 차단하기 위한 단클론 항체(monoclonal antibody)가 개발되고 악성 흑색종, 신장암 및 비소세 포폐암과 같은 암 환자의 치료에 적용한 전임상 및 임상연구 성적이 발표되면서, 새로운 암 면역 치료 방법의 하나로 기대 를 모으고 있다.

세포독성 $\mathrm{T}$ 림프구 연관 항원(Cytotoxic $\mathrm{T}$ lymphocyteassociated antigen, CTLA-4)

CTLA-4는 최초로 임상 치료 표적으로 연구된 면역 관문 수용체로서, 세포독성 $\mathrm{T}$ 림프구의 표면에서 $\mathrm{T}$ 림프구 수용체 (T cell receptor, TCR) ligation 이후에 발현되는 당단백 수 용체이다(Fig. 1A). 원래 CTLA-4의 역할은 만성적인 항원 자극에 대해 과다한 면역반응을 억제함으로써 자가면역의 발생을 막아주는 것이나, 암 환자의 혈중 Treg에서 CTLA-4 의 발현이 정상 대조군에 비해 증가하는 것으로 밝혀져 있 고, 이로 인해 암에 의한 부적절한 면역 관용(tolerance)와 면 역 회피(immune escape)에 기여하는 것으로 생각된다. ${ }^{24)}$ CTLA-4는 상호 자극성 수용체인 CD28과 경쟁적으로 항원 제시세포의 B7 리간드에 결합하게 되는데, CTLA-4가 $\mathrm{CD} 28$ 보다 B7 리간드에 대해 친화성(affinity)이 더 높은 것 으로 알려져 있다. ${ }^{25)}$ 이러한 친화성 차이로 인해 CTLA-4는 CD28-B7 결합에 의한 면역자극을 효과적으로 억제함으로 써 $\mathrm{T}$ 림프구 기능을 하향 조절(down regulation)하게 되며, $\mathrm{T}$
림프구 세포주기 마비(cell cycle arrest)를 유도하게 된다. ${ }^{26-30)}$ 이때, CTLA-4의 작용을 단클론항체로 차단하면 CD28과

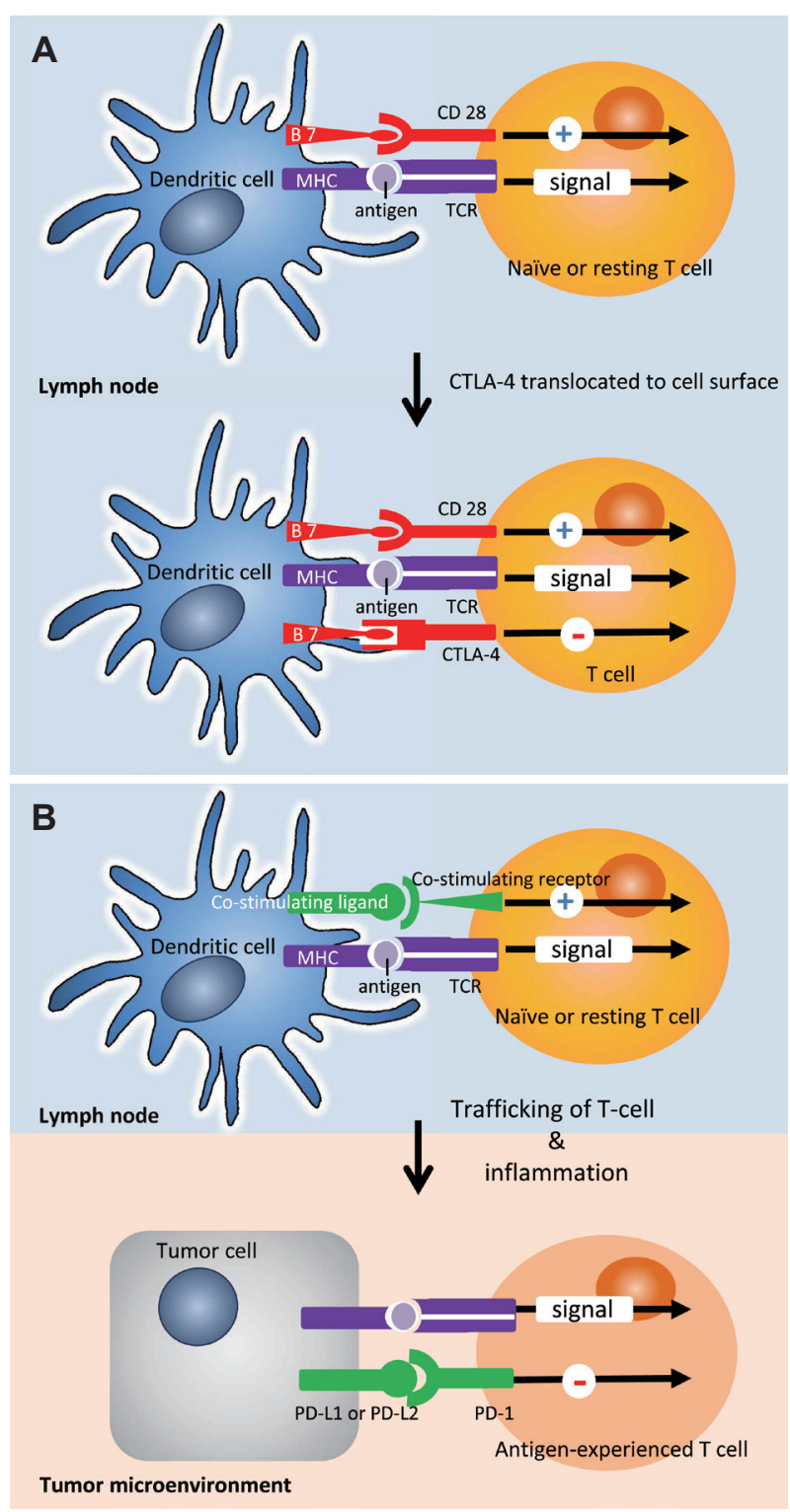

Fig. 1. The Immune check point. The cytotoxic T lymphocyte-associated antigen 4 (CTLA-4). For activation of T lymphocyte, antigens complexed with major histocompatibility complex (MHC) were presented to T cell receptor (TCR) by antigen presenting cell (dendritic cell). At this time, costimulatory signal between B7 on an antigen presenting cell and CD 28 on the T lymphocyte have an important role. Early after T lymphocyte activation, plasma membrane expression of CTLA-4 downregulates functions of T lymphocyte for immunologic homeostatic maintenance $(A)$. The programmed cell death protein-1 (PD-1). PD-1 regulates immune response of T lymphocyte about inflammatory reaction to infection in tissues. PD-L1/ PD-L2 is induced by inflammatory response in tissue, and binds to PD-1 receptor expressed on T lymphocyte. As a result, this signal downregulate T lymphocyte to minimize additional tissue damage in response to continuous immune reaction. In tumor microenvironment, when PD-L1/PD-L2 expressed on tumor cell binds to $\mathrm{PD}-1$ on the effector T lymphocyte in tumor microenvironment, this interaction suppress anti-tumor immune response of T lymphocyte (B). 
$\mathrm{B} 7$ 이 결합하여, 면역자극에 필요한 $\mathrm{TCR}$ 신호를 유도하게 되어 세포독성 $\mathrm{T}$ 림프구에 의한 암항원에 대한 세포용해(cytolysis)가 증가하게 되고, 이를 통해 암세포 억제 효과가 발생 하게 된다.

CTLA-4를 대상으로 하는 단클론항체로 The Food and Drug Administration(FDA) 승인을 받은 최초의 약제인 ipilimumab(Bristol-Myers Squibb, New York, NY, USA)과 현재 다양한 임상연구가 진행 중에 있는 tremelimumab(formerly Pfizer, currently MedImmune/AstraZeneca, Wilmington, DE, USA)가 있다. Ipilimumab은 억제성 CTLA-4 기 전을 차단하는 $\mathrm{IgG} 4$ 단클론항체인데, 진행된 흑색종 환자를 대상으로 한 서로 다른 2 개의 임상 3 상 연구에서 전체 생존 율의 향상을 보이면서 $\mathrm{FDA}$ 승인을 받은 최초의 면역 관문 차 단 약제이다. Hodi 등 ${ }^{31)}$ 에 의한 전이성 흑색종(3 4병기)을 대 상으로 한 연구에서, glycoprotein 100(gp100) 또는 ipilimumab 단독투여 대조군과 gp100과 ipilimumab을 같이 투여 한 실험군으로 나눠 생존율을 비교한 결과, ipilimumab(단 독 또는 병합투여 모두) 투여군의 생존율이 gp100 단독 투여 군에 비해 유의하게 증가하였다(10.0개월 Vs. 6.4개월). Prieto 등 ${ }^{32)}$ 의 보고는, 앞서 연구와 동일한 전이성 흑색종 환자를 대 상으로 ipilimumab 치료를 시행하고, 평균 71개월 이상 장기 추적 관찰을 하였는데, ipilimumab과 IL-2를 같이 투여한 군의 평균 생존율이 16 개월로 가장 우수하였고, 특히 완전 관 해를 보인 환자도 $17 \%$ 로 높게 보고되었는데, ipilimumab 치 료 종료 이후에도 지속적인 암 관해가 나타난 결과로 해석하 였다. 이는, 면역 치료 종료 후에도 비교적 지속되는 암 억제 및 치료 효과를 보였다는 점에서 다시 한번 주목받았다. 두경 부암에서도 암 주변 미세환경 내 Treg의 CTLA-4 발현이 증 가되어 있다는 점을 고려하면, ipilimumab에 의한 치료 효과 를 기대해 볼 수 있는데, 유방암과 대장암의 분할조사 방사선 요법(fractionated radiotherapy)에서 CTLA-4 단일클론항체 를 같이 사용하였을 때 방사선 조사 영역 밖의 이차 종양 성장 이 억제되는 부수적인 효과를 보이는 연구를 근거로, ${ }^{33)}$ 현재 국소적으로 진행된 두경부암 환자군을 대상으로 cetuximab, intensity modulated radiotherapy와 함께 ipilimumab을 사 용하는 임상 1상 연구가 진행 중이다(NCT0186430).

Tremelimumab은 CTLA-4와 높은 친화성을 보이는 IgG2 단클론항체로서, Camacho 등 ${ }^{34)}$ 이 시행한 악성 흑생종 환자 를 대상으로 한 $1 / 2$ 상 임상연구에서 ipilimumab과 유사한 효과를 보였다. 특히, 89명을 포함시킨 임상 2상 연구에서 $10 \%$ 의 종양 반응률을 보이면서, 1 명의 완전 관해와 3 명의 부 분 관해를 보고하였고, grade $3 / 4$ 이상 반응은 약제용량에 따 라서 13 27\%로 나타났다. 현재 진행성 중피종 환자를 대상으
로 2상 임상연구가 진행 중이며, 비소세포성 폐암 환자를 대 상으로 서로 다른 종류의 면역 관문 차단제 병합요법에 대한 2상 임상연구가 진행 중이다(NCT01843374). 추후, 임상연구 결과에 따라서, 두경부암에서의 효과에 대한 연구도 기대해 볼 수 있을 것이다.

\section{계획된 세포소멸 단백질(Programmed cell death} protein-1, PD-1)

PD-1 역시, B7-CD28 family에 속하는 상호 억제성 수용체 의 일종이며, TCR 활성화 이후 CTLA-4보다 더 다양한 종류 의 면역세포(세포독성 $\mathrm{T}$ 림프구, 자연살해세포, $\mathrm{B}$ 림프구, 단 핵구, 수지상세포 등)에서 발현된다(Fig. 1B). PD-1의 리간드 인 PD-L1은 IFN- $\gamma$ 의 자극에 의해 비조혈성 조직(non-hematopoietic tissue)에 전반적으로 발현되는데, PD-1 수용체와 의 결합을 통해 nuclear factor kappa-light-chain-enhancer of activated B cells 전사(transcription) 및 IFN- $\gamma$ 분비를 억 제함으로써, 감염 반응 중 자가면역반응이나 면역 공격으로 부터 정상 조직을 보호하는 것으로 생각된다. ${ }^{35)} \mathrm{CTLA}-4$ 와 유사하게 PD-1도 Treg 림프구에서 강하게 발현되는데, Treg 림프구가 암 조직 내로 많이 침윤되어 있는 점을 감안할 때, PD-1 기전을 차단하게 되면 암 조직 내 Treg 림프구 억제를 유발하여 암세포 억제 면역 반응을 유도할 수 있게 된다. 또한, 많은 종류의 상피암(epithelial cancer)에서 세포 표면의 PD-L1 이 과발현되면서 $\mathrm{PD}-1$ 경로가 증진되어, $\mathrm{T}$ 림프구의 무감작 상태가 발생하게 되고 항원제시세포들의 종양항원의 인식 및 제시과정이 억제된다. 이러한 PD-L1의 과발현이 비소세포 성 폐암환자에서 19 100\%까지 관찰된다는 점에서, $\mathrm{PD}-1 / \mathrm{PD}-$ L1 기전은 임상적으로 응용할 만한 표적이 될 수 있다..$^{36-39)}$

흥미로운 점은 두경부암 대부분에서도 $\mathrm{PD}-\mathrm{L} 1$ 의 발현이 관찰되는데 1) 전반적으로 암 세포의 PD-L1 발현이 높을수 록 암침윤림프구(tumor-infiltrating lymphocyte)가 적게 나 타나는 점, ${ }^{40)}$ 2) Human papillomavirus(HPV) 양성 두경부 암에서 암침윤림프구가 높은 PD-1 발현을 보이고, 가장 침 습적인 암 전방부위(invasive front)에서 높은 PD-L1 발현 이 보고된 점, ${ }^{41)}$ 3) $\mathrm{HPV}$ 음성 두경부암에서도 $78 \%$ 이상에서 높은 암세포의 PD-L1 발현을 보이고 암침윤림프구의 PD-1 역시 발현이 증가된 점 ${ }^{42}$ 등의 연구결과를 고려해 볼 때, 두 경부암에서도 PD-1 차단을 통한 암 조절 및 치료 효과를 기 대해 볼 수 있다.

현재 임상연구 단계에 있는 PD-1/PD-L1 관련 항체는 PD-1 을 표적으로 하는 Nibolumab(BMS-936558, Bristol-Myers Squibb, New York, NY, USA), Pembrolizumab(Merck, Whitehouse Station, NY, USA), Pidilizumab(CureTech, Yavne, Is- 
rael), Lambrolizumab(MK-3475, Merck, Whitehouse Station, $\mathrm{NY}, \mathrm{USA}$ ) 등이 있고, PD-L1을 표적으로 하는 항체는 MPDL3280A(Genentech, San Francisco, CA, USA), BMS-936559 (Bristol-Myers Squibb, New York, NY, USA), MEDI4736(AstraZeneca, London, United Kingdom) 등이 있다.

PD-1 단클론항체인 nivolumab과 pembrolizumab 모두, 진 행된 악성 흑색종, 비소세포성 폐암, 신장암 및 기타 고형암 환자를 대상으로 한 대규모 임상 1 상 연구에서 의미있고, 지속 적인 치료 반응이 보고되면서, 이후 많은 후속 임상연구들이 진행되는 계기가 되었다. Topalian 등 ${ }^{43}$ 은 비소세포성 폐암, 흑 생종, 신장암 등을 대상으로 nivolumab을 투여한 연구에서 18 28\% 정도의 1년 이상 지속되는 치료반응률을 보고하였 고, Hamid 등 ${ }^{44}$ 은 CTLA-4 단클론 항체인 ipilimumab에 반 응이 없는 흑색종 환자를 포함하여 lambrolizumab을 투여 한 연구에서 $38 \%$ 의 치료반응률을 보고하였다. Robert 등 ${ }^{45}$ 에 의한 임상 3상 연구에서는 BRAF mutation이 없는 흑색 종 환자에서 nivolumab을 투여 후 1년째 생존율이 $72.9 \%$ 로, 대조군의 $42.1 \%$ 에 비해 유의하게 향상된다고 보고하였다. Nivolumab은 단독 치료뿐 아니라 병합 요법에 대한 임상연구 도 활발히 진행 중인데, 비소세포성 폐암 환자에서 nivolumab 과 platinum-based chemotherapy의 병합 요법을 시행한 경우 $33 \%$ 의 치료 반응률을 보였고, 이외에도 흑색종에서 nivolumab 과 다른 종류의 면역 관문 치료제와 병합 요법에 따른 시너 지 효과에 대한 임상연구가 진행 중이다. Pembrolizumab 역 시 유의한 치료 반응률 성적을 보여서 최근 ipilimumab 치료 력이 있는 흑색종 환자에 대해 미국 FDA 승인을 받았다.

$\mathrm{PD}-\mathrm{L} 1$ 에 대한 항체는, $\mathrm{B} 7$ 과 상호작용을 통한 $\mathrm{T}$ 림프구 억제 신호를 차단하면서, PD-1 수용체와 PD-L2 사이의 반응 은 유지한다는 점에서 $\mathrm{PD}-1$ 항체와는 작용 기전이 다른 것으 로 생각된다. 그 중 BMS-956559는 IgG4 단클론항체로서 여러 가지 고형암에서 객관적인 반응률을 보인 항체이며, 기 타 다른 약제 역시 방광암, 소화기암을 대상으로 한 임상연 구에서 주목할 만한 성적을 보였다.

아직까지 두경부암 환자를 대상으로 PD-1/PD-L1 항체를 이용한 임상연구가 완결되어 보고된 바는 없지만, 현재 활발 하게 연구가 진행 중인 분야이며, 여러 가지 예비 안전성 보고 등은 꾸준히 발표되고 있다. Pembrolizumab을 이용한 임상 1 상 연구(안전성 연구)에서, $\mathrm{PD}-\mathrm{L} 1$ 발현이 입증된 재발성/전 이성 두경부암 환자에게 투여하였고, 한 가지 이상의 이상 반 응이 $78.3 \%$ 에서 보였고 그 중 $46.7 \%$ 가 약제 관련 반응이었다 고 보고하였다(NCT01848834). Platinum 약제에 저항성을 보 이는 재발성/전이성 두경부암을 포함하여 여러 부위의 암에 대한 nivolumab 임상 3 상 연구 중간 결과 발표에서, 추적 관
찰 6주 이후에 두경부암 환자에서 약제 반응을 관찰하였다고 보고하였다(NCT02105636). 또한, 두경부암 환자만을 대상 으로 하여 nivolumab의 효과를 비교하는 임상 3상 연구가 진 행 중이며 2017년경 결과가 발표될 예정이다(NCT02105636).

\section{해결해야 할 문제점}

\section{면역 관련 이상 반응}

면역 관문 차단 요법에 의해 암에 대한 특이적인 면역 반응 이 유도되는 과정에서, 비특이적인 면역 활성화로 인해 기존 의 항암화학요법과는 다른 이상 반응(immune-related adverse effect)이 관찰될 수 있으나, grade $3 / 4$ 의 이상 반응 빈도 는 대개 10 20\% 정도로, 표준항암화학요법이나 표적치료요 법과 크게 다르지 않다. 구체적으로, ipilimumab의 경우, 10 $15 \%$ 의 grade $3 / 4$ 이상 반응이 보고되는데, 그 중 $2 \%$ 정도의 환자가 약물 반응의 결과로 사망하는 것으로 알려져 있고, nivolumab 역시 $14 \%$ 정도 grade $3 / 4$ 이상 반응률과 $1 \%$ 의 사 망률이 나타나고 있다. 또한, 두 약제를 병합 사용한 연구에 서, grade $3 / 4$ 이상의 반응이 53\%까지 높게 보고되어 있다. 가 장 흔한 이상 반응은 사지나 몸통에 발생하는 홍반, 발진 등 의 피부과적 독성 반응이며, 이 외에도 임상적으로 문제가 되 는 설사/장염 등의 소화기계 문제도 나타날 수 있는데, 설사 의 경우 치료와 연관된 사망으로 이어진 경우도 보고되어 있어 서 주의가 필요하다. 그 외, 간효소의 혈장수치 상승이나 내분 비계통의 증상이 나타날 수 있다. 면역 치료 시 발생하는 이상 반응에 대해서 부신피질스테로이드(corticosteroid)를 주 치료 로 사용하게 된다. 면역 치료는 다른 항암화학요법이나 표적 치료제와 병합으로 유지하는 경우가 많기 때문에, 심각한 이 상 반응 발생과 조절 가능 여부가 면역 치료법의 임상 적용을 위한 중요한 요인이라고 할 수 있다.

\section{치료 반응을 예측할 수 있는 생체표지자(Biomarkers)}

면역 관문 차단제에 의해 효과를 볼 수 있는 암 종류를 사 전에 알 수 있다면, 적절한 차단제를 선택하고 예후를 예측 하는 데 도움을 줄 수 있을 것이다. CTLA-4 기전의 차단에 의 해 말초혈액 내 $\mathrm{T}$ 림프구의 활성화와 증식이 유도되는 것을 근거로, ipilimimab에 대한 약물동력학적 생체표지자로 말 초 혈액 내 림프구의 절대 숫자, 또는 그 증가 정도가 전체 생 존율과 상관성이 있다는 연구결과가 있으며, 암 조직 내에서 Treg의 수, 면역억제 효소나 면역활성과 연관된 유전자 변화 등이 ipilimumab에 대한 치료 반응률과 연관이 있다고 알려 져 있어서 생체표지자로서 가능성이 있다고 볼 수 있으나, 추 가적인 연구가 필요하겠다. 
PD-1/PD-L1에 의한 면역 관문 차단은 여러 단계의 면역 반응에 관여하지만 핵심적으로 미세환경 내에서 암세포와 $\mathrm{T}$ 림프구에 영향을 미치는 것으로 알려져 있다. 이를 뒷받침하 는 결과로, 면역조직화학염색법에 의해 PD-L1을 발현하는 암종이 발현하지 않는 암종에 비해 PD-1에 대해 높은 치료 반응률을 보이는 것으로 보고되고 있다. ${ }^{46)}$ 하지만 PD-L1발 현이 낮은 암에서도 유의할만한 PD-1 반응을 보이기도 하 며, PD-L1의 발현이 다양한 환경에 따라 유도되거나 증가할 수 있다는 점에서 치료 반응을 예측하는 인자로서 PD-L1의 의미는 연구가 더 필요한 상황이다.

\section{다른 치료와 병합요법}

면역 관문 치료제들은 기존의 항암화학요법, 표적치료요법 및 방사선 요법 등과 병합을 통해, 치료 효과를 증가시키려는 연구가 많이 진행 중에 있다. 항암화학요법의 경우, 항암화학 치료 자체가 면역억제 효과가 있어서 면역 치료와의 병합시 면 역 치료의 역할이 의문시되었으나, 한 연구에서 비소세포성 폐 암과 흑색종 환자에 대한 병합 요법 후 이상 반응 빈도가 증 가하지 않았다는 보고가 있어서, 추후 면역항체의 용량과 투 여 스케줄에 대한 무작위 배정 임상연구를 통한 검증이 필 요한 상황이다. 흑색종의 BRAF 돌연변이(mutation)에 대한 표적치료제와 면역 관문 치료제의 조합처럼 다양한 병합 요법 에 대한 전임상연구가 시도되고 있으나, 아직까지는 이상 반 응의 문제를 해결하지 못한 상태이며 추가 연구가 필요하다. 방사선 요법 역시 전임상연구에서 CTLA-4와 PD-1 차단에 의 한 면역 치료 효과를 증가시킬 것으로 추정되고 있으나 현재 진행 중인 전향적 임상연구의 결과를 기다려야 하는 상황이다.

\section{결 론}

암의 발생과 진행 과정에 다양한 면역 기전이 작용하는 것 은 오래 전부터 알려져 왔으나, 최근 면역 관문 차단 기전 및 이와 관련된 항체의 개발, 이를 이용한 전임상/초기 임상연구 에서 좋은 성적이 발표되면서 다시 주목 받기 시작하였다. 아 직까지 면역 치료 관련 이상 반응, 적절한 용량과 투여 스케 줄, 타 치료법과 병합 요법 시 면역 치료에 의한 부가적인 효과 의 판정 등의 문제가 남아있지만, 면역 관문 차단 치료제는 환자의 자연적인 항암면역 능력을 이용하는 한편, 기존 항암 치료요법의 효과를 증가시킬 수 있다는 점에서 새로운 암 치 료 전략이 될 수 있는 가능성이 높으며, 앞으로 현재 진행 중 인 많은 전향적 임상연구의 결과를 주의 깊게 지켜볼 필요가 있겠다.

\section{REFERENCES}

1) Naidoo J, Page DB, Wolchok JD. Immune checkpoint blockade. Hematol Oncol Clin North Am 2014;28(3):585-600.

2) Kuss I, Hathaway B, Ferris RL, Gooding W, Whiteside TL. Imbalance in absolute counts of T lymphocyte subsets in patients with head and neck cancer and its relation to disease. Adv Otorhinolaryngol 2005;62:161-72.

3) Schaefer C, Kim GG, Albers A, Hoermann K, Myers EN, Whiteside TL. Characteristics of CD4+CD25+ regulatory $T$ cells in the peripheral circulation of patients with head and neck cancer. $\mathrm{Br} \mathrm{J}$ Cancer 2005;92(5):913-20.

4) Strauss L, Bergmann C, Szczepanski M, Gooding W, Johnson JT, Whiteside TL. A unique subset of CD4+CD25highFoxp3+ T cells secreting interleukin-10 and transforming growth factor-betal mediates suppression in the tumor microenvironment. Clin Cancer Res 2007;13(15 Pt 1):4345-54.

5) Li C, Shintani S, Terakado N, Nakashiro K, Hamakawa H. Infiltration of tumor-associated macrophages in human oral squamous cell carcinoma. Oncol Rep 2002;9(6):1219-23.

6) Grandis JR, Falkner DM, Melhem MF, Gooding WE, Drenning SD, Morel PA. Human leukocyte antigen class I allelic and haplotype loss in squamous cell carcinoma of the head and neck: clinical and immunogenetic consequences. Clin Cancer Res 2000;6(7):2794-802.

7) Whiteside TL. Immunobiology of head and neck cancer. Cancer Metastasis Rev 2005;24(1):95-105.

8) Gabrilovich DI, Chen HL, Girgis KR, Cunningham HT, Meny GM, Nadaf S, et al. Production of vascular endothelial growth factor by human tumors inhibits the functional maturation of dendritic cells. Nat Med 1996;2(10):1096-103.

9) Benefield J, Petruzzelli GJ, Fowler S, Taitz A, Kalkanis J, Young MR. Regulation of the steps of angiogenesis by human head and neck squamous cell carcinomas. Invasion Metastasis 1996;16(6):291301.

10) Schroeder CP, Yang P, Newman RA, Lotan R. Eicosanoid metabolism in squamous cell carcinoma cell lines derived from primary and metastatic head and neck cancer and its modulation by celecoxib. Cancer Biol Ther 2004;3(9):847-52.

11) Qin H, Valentino J, Manna S, Tripathi PK, Bhattacharya-Chatterjee $\mathrm{M}$, Foon KA, et al. Gene therapy for head and neck cancer using vaccinia virus expressing IL-2 in a murine model, with evidence of immune suppression. Mol Ther 2001;4(6):551-8.

12) Agada FO, Alhamarneh O, Stafford ND, Greenman J. Immunotherapy in head and neck cancer: current practice and future possibilities. $\mathrm{J}$ Laryngol Otol 2009;123(1):19-28.

13) Postow MA, Callahan MK, Barker CA, Yamada Y, Yuan J, Kitano $\mathrm{S}$, et al. Immunologic correlates of the abscopal effect in a patient with melanoma. N Engl J Med 2012;366(10):925-31.

14) Stamell EF, Wolchok JD, Gnjatic S, Lee NY, Brownell I. The abscopal effect associated with a systemic anti-melanoma immune response. Int J Radiat Oncol Biol Phys 2013;85(2):293-5.

15) Bauman JE, Ferris RL. Integrating novel therapeutic monoclonal antibodies into the management of head and neck cancer. Cancer 2014;120(5):624-32.

16) Whiteside TL, Letessier E, Hirabayashi H, Vitolo D, Bryant J, Barnes L, et al. Evidence for local and systemic activation of immune cells by peritumoral injections of interleukin 2 in patients with advanced squamous cell carcinoma of the head and neck. Cancer Res 1993;53(23):5654-62.

17) De Stefani A, Forni G, Ragona R, Cavallo G, Bussi M, Usai A, et al. Improved survival with perilymphatic interleukin 2 in patients with resectable squamous cell carcinoma of the oral cavity and oropharynx. Cancer 2002;95(1):90-7.

18) Chi KH, Myers JN, Chow KC, Chan WK, Tsang YW, Chao Y, et al. Phase II trial of systemic recombinant interleukin-2 in the treatment 
of refractory nasopharyngeal carcinoma. Oncology 2001;60(2):110-5.

19) Egan JE, Quadrini KJ, Santiago-Schwarz F, Hadden JW, Brandwein HJ, Signorelli KL. IRX-2, a novel in vivo immunotherapeutic, induces maturation and activation of human dendritic cells in vitro. J Immunother 2007;30(6):624-33.

20) Wolf GT, Fee WE Jr, Dolan RW, Moyer JS, Kaplan MJ, Spring PM, et al. Novel neoadjuvant immunotherapy regimen safety and survival in head and neck squamous cell cancer. Head Neck 2011;33(12): 1666-74.

21) Berinstein NL, Wolf GT, Naylor PH, Baltzer L, Egan JE, Brandwein $\mathrm{HJ}$, et al. Increased lymphocyte infiltration in patients with head and neck cancer treated with the IRX-2 immunotherapy regimen. Cancer Immunol Immunother 2012;61(6):771-82.

22) Schuler PJ, Harasymczuk M, Visus C, Deleo A, Trivedi S, Lei Y, et al. Phase I dendritic cell p53 peptide vaccine for head and neck cancer. Clin Cancer Res 2014;20(9):2433-44.

23) Kyi C, Postow MA. Checkpoint blocking antibodies in cancer immunotherapy. FEBS Lett 2014;588(2):368-76.

24) Strauss L, Bergmann C, Gooding W, Johnson JT, Whiteside TL. The frequency and suppressor function of CD4+CD25highFoxp3+ T cells in the circulation of patients with squamous cell carcinoma of the head and neck. Clin Cancer Res 2007;13(21):6301-11.

25) Linsley PS, Greene JL, Brady W, Bajorath J, Ledbetter JA, Peach R. Human B7-1 (CD80) and B7-2 (CD86) bind with similar avidities but distinct kinetics to CD28 and CTLA-4 receptors. Immunity 1994; 1(9):793-801.

26) Linsley PS, Brady W, Urnes M, Grosmaire LS, Damle NK, Ledbetter JA. CTLA-4 is a second receptor for the B cell activation antigen B7. J Exp Med 1991;174(3):561-9.

27) Schneider H, Downey J, Smith A, Zinselmeyer BH, Rush C, Brewer JM, et al. Reversal of the TCR stop signal by CTLA-4. Science 2006; 313(5795):1972-5.

28) Riley JL, Mao M, Kobayashi S, Biery M, Burchard J, Cavet G, et al. Modulation of TCR-induced transcriptional profiles by ligation of CD28, ICOS, and CTLA-4 receptors. Proc Natl Acad Sci U S A 2002;99(18):11790-5.

29) Qureshi OS, Zheng Y, Nakamura K, Attridge K, Manzotti C, Schmidt EM, et al. Trans-endocytosis of CD80 and CD86: a molecular basis for the cell-extrinsic function of CTLA-4. Science 2011;332 (6029):600-3.

30) Krummel MF, Allison JP. CTLA-4 engagement inhibits IL-2 accumulation and cell cycle progression upon activation of resting T cells. J Exp Med 1996;183(6):2533-40.

31) Hodi FS, O’Day SJ, McDermott DF, Weber RW, Sosman JA, Haanen $\mathrm{JB}$, et al. Improved survival with ipilimumab in patients with metastatic melanoma. N Engl J Med 2010;363(8):711-23.

32) Prieto PA, Yang JC, Sherry RM, Hughes MS, Kammula US, White DE, et al. CTLA-4 blockade with ipilimumab: long-term follow-up of 177 patients with metastatic melanoma. Clin Cancer Res 2012; 18(7):2039-47.

33) Dewan MZ, Galloway AE, Kawashima N, Dewyngaert JK, Babb
JS, Formenti SC, et al. Fractionated but not single-dose radiotherapy induces an immune-mediated abscopal effect when combined with anti-CTLA-4 antibody. Clin Cancer Res 2009;15(17):5379-88.

34) Camacho LH, Antonia S, Sosman J, Kirkwood JM, Gajewski TF, Redman B, et al. Phase I/II trial of tremelimumab in patients with metastatic melanoma. J Clin Oncol 2009;27(7):1075-81.

35) Wang S, Bajorath J, Flies DB, Dong H, Honjo T, Chen L. Molecular modeling and functional mapping of B7-H1 and B7-DC uncouple costimulatory function from PD-1 interaction. J Exp Med 2003; 197(9):1083-91.

36) Konishi J, Yamazaki K, Azuma M, Kinoshita I, Dosaka-Akita H, Nishimura M. B7-H1 expression on non-small cell lung cancer cells and its relationship with tumor-infiltrating lymphocytes and their PD-1 expression. Clin Cancer Res 2004;10(15):5094-100.

37) Mu CY, Huang JA, Chen Y, Chen C, Zhang XG. High expression of PD-L1 in lung cancer may contribute to poor prognosis and tumor cells immune escape through suppressing tumor infiltrating dendritic cells maturation. Med Oncol 2011;28(3):682-8.

38) Hirahara K, Ghoreschi K, Yang XP, Takahashi H, Laurence A, Vahedi $\mathrm{G}$, et al. Interleukin-27 priming of T cells controls IL-17 production in trans via induction of the ligand PD-L1. Immunity 2012;36(6):101730.

39) Wölfle SJ, Strebovsky J, Bartz H, Sähr A, Arnold C, Kaiser C, et al. PD-L1 expression on tolerogenic APCs is controlled by STAT-3. Eur J Immunol 2011;41(2):413-24.

40) Cho YA, Yoon HJ, Lee JI, Hong SP, Hong SD. Relationship between the expressions of PD-L1 and tumor-infiltrating lymphocytes in oral squamous cell carcinoma. Oral Oncol 2011;47(12):1148-53.

41) Lyford-Pike S, Peng S, Young GD, Taube JM, Westra WH, Akpeng $\mathrm{B}$, et al. Evidence for a role of the PD-1:PD-L1 pathway in immune resistance of HPV-associated head and neck squamous cell carcinoma. Cancer Res 2013;73(6):1733-41.

42) Malm IJ, Bruno TC, Fu J, Zeng Q, Taube JM, Westra W, et al. Expression profile and in vitro blockade of programmed death-1 in human papillomavirus-negative head and neck squamous cell carcinoma. Head Neck 2014 Apr 7 [Epub]. http://dx.doi.org/10.1002 /hed.23706

43) Topalian SL, Hodi FS, Brahmer JR, Gettinger SN, Smith DC, McDermott DF, et al. Safety, activity, and immune correlates of anti-PD-1 antibody in cancer. N Engl J Med 2012;366(26):2443-54.

44) Hamid O, Robert C, Daud A, Hodi FS, Hwu WJ, Kefford R, et al. Safety and tumor responses with lambrolizumab (anti-PD-1) in melanoma. N Engl J Med 2013;369(2):134-44.

45) Robert C, Long GV, Brady B, Dutriaux C, Maio M, Mortier L, et al. Nivolumab in previously untreated melanoma without BRAF mutation. N Engl J Med 2015;372(4):320-30.

46) Taube JM, Klein A, Brahmer JR, Xu H, Pan X, Kim JH, et al. Association of PD-1, PD-1 ligands, and other features of the tumor immune microenvironment with response to anti-PD-1 therapy. Clin Cancer Res 2014;20(19):5064-74.

\section{정답 및 해설}

(3)

해 설 Transcutaneous(closed-skin) bone-conduction device인 Sophono기기를 수술하는 사진으로 전음성 난청의 경우 피 부를 관통하는 abutment가 없는 장점이 있다. Cummings. 6th ed. p.3015-8. 